\title{
High expression of XIAP and Bcl-2 may inhibit programmed cell death in glioblastomas
}

\author{
Alta expressão de XIAP e Bcl-2 pode inibir morte celular programada em glioblastomas \\ Daniela Pretti da Cunha Tirapelli', Isis Lacrose Lustosa', Sarah Bomfim Menezes', Indira Maynart Franco', \\ Andressa Romualdo Rodrigues', Fernanda Maris Peria², Alexandre Magno da Nóbrega Marinho³, Luciano \\ Neder Serafini4 , Carlos Gilberto Carlotti Jr', Luís Fernando Tirapelli ${ }^{1}$
}

\begin{abstract}
Glioblastoma (GBM) is the most malignant glioma and represents $29 \%$ of all brain tumors. Tumorigenesis is intimately connected with characteristics acquired in the physiologic pathway of cellular death. Objective: In the present study, the expression of anti-apoptotic (XIAP and Bcl-2) and apoptotic (cytochrome C, caspase 9, APAF-1), caspase 3 and the Smac/DIABLO genes related to the apoptosis pathway were evaluated in 30 samples of glioblastoma. Methods: The gene expression was evaluated in 30 glioblastomas (WHO grade IV) and compared to 10 white matter control samples with real-time PCR. Results and Conclusion: There were higher expressions of XIAP ( $p=0.0032)$ and $\mathrm{Bcl}-2(p=0.0351)$ in the glioblastoma samples compared to the control samples of normal brain. These results raise the question of whether $\mathrm{Bcl}-2$ and XIAP genes can be responsible for the inhibition of programmed cell death in glioblastomas. Moreover, they provide additional information capable of allowing the development of new target therapy strategies.
\end{abstract}

Keywords: glioblastoma; apoptosis; X-linked inhibitor of apoptosis protein; B-cell lymphoma 2.

\section{RESUMO}

O glioblastoma (GBM) é o glioma mais maligno e representa 29\% de todos os tumores cerebrais. A tumorigênese está intimamente ligada à características adquiridas na via fisiológica de morte celular. Objetivo: Avaliar a expressão de genes anti-apoptóticos (XIAP e $\mathrm{Bcl}$-2) e apoptóticos (citocromo C, a caspase 9, APAF-1), caspase 3 e SMAC/DIABLO, relacionados à apoptose, em 30 amostras de tecido de pacientes com glioblastoma. Métodos: A expressão gênica foi avaliada em trinta glioblastomas e comparada a dez amostras controles de substância branca por PCR em tempo real. Resultados e Conclusão: Houve maior nível de expressão de XIAP ( $p=0,0032$ ) e Bcl-2 ( $p=0,0351$ ) em comparação com as amostras controle, de cérebro normal. Estes resultados levantam a questão de que os genes Bcl-2 e XIAP podem ser responsáveis pela inibição da morte celular programada em glioblastomas, além disso, proporcionam informação adicional capaz de permitir o desenvolvimento de novas estratégias de terapia alvo.

Palavras-chave: glioblastoma; apoptose, proteínas inibidoras de apoptose ligadas ao cromossomo X; célula-B de linfoma 2.

Despite recent advances in the understanding of high-grade gliomas, they are among the most malignant of all cancers, with dismal patient outcomes. The classification of gliomas follows the World Health Organization (WHO) classification, which is based on knowledge of cytologic features and degrees of malignancy. The most aggressive form of glioma, the glioblastoma (GBM), represents $29 \%$ of primary brain tumors and about $55 \%$ of all gliomas ${ }^{1,2,3}$. In spite of standard treatment with surgery, chemotherapy with temozolomide, and radiotherapy, glioblastomas are always fatal with a median survival rate of less than a year and a five-year survival rate of less than $10 \%$ of the cases ${ }^{4,5,6,7}$.

The glioblastomas are characterized by complex heterogeneity. A new definition of this heterogeneity was recently proposed based on genomic, transcriptomic and epigenomic studies carried out by The Cancer Genome Atlas Network. Through the latter's analyses, the GBMs were clustered into four subgroups: proneural, neural, classical and mesenchymal, which correlate with biological properties of the tumors and measures of clinical outcome ${ }^{8,9}$.

1. Universidade de São Paulo, Departamento de Cirurgia e Anatomia, Ribeirão Preto SP, Brasil;

2. Universidade de São Paulo, Departamento de Medicina Interna, Ribeirão Preto SP, Brasil;

3. Universidade Federal de Campina Grande, Unidade Acadêmica de Ciências Médicas, Campina Grande PB, Brazil;

4. Universidade de São Paulo, Faculdade de Medicina de Ribeirão Preto, Departamento de Patologia e Medicina Legal, Ribeirão Preto SP, Brasil.

Correspondence: Daniela Pretti da Cunha Tirapelli; Departamento de Cirurgia e Anatomia da USP; Avenida dos Bandeirantes, 3900 ; $14049-900$ Ribeirão Preto SP, Brasil; E-mail: lab.biomol.cirurgia@fmrp.usp.br

Conflict of interest: There is no conflict of interest to declare.

Received 11 August 2016; Received in final form 02 August 2017; Accepted 14 August 2017. 
Tumorigenesis is intimately connected with heredity or acquired defects in physiological pathways of cellular death. Defects may include loss of a tumor suppressor gene such as the TP53, enhanced expression of anti-apoptotic genes or reduction of the expression of apoptotic gene products such as Bcl-2 and BAX, respectively ${ }^{4}$. Knowing the mechanisms of apoptosis makes it possible to support the development of new drugs that target specific apoptotic pathways or genes ${ }^{10}$.

The intrinsic pathway of cellular apoptosis is triggered in response to a wide range of death stimuli that are generated within the cell. The intrinsic pathway is mediated by mitochondria and, in response to apoptotic stimuli, several proteins are released from the intermembrane space of mitochondria into the cytoplasm. The release of mitochondrial proteins (such as cytochrome C) is mediated by BAK and BAX, which make up part of the multidomain pro-apoptotic members of Bcl-2 family proteins. Some of the well-described proteins include cytochrome $\mathrm{C}$, second mitochondria-derived activator of caspase (Smac)/direct inhibitor of apoptosis (DIABLO), and apoptosis-inducing factor. The most intriguing of the pro-apoptotic proteins is cytochrome $\mathrm{C}$, which binds to and activates the protein APAF-1 in the cytoplasm. The binding of cytochrome $\mathrm{C}$ to APAF-1 induces a conformational change that allows APAF-1 to bind to ATP/dATP resulting in the apoptosome molecule, which mediates activation of caspase-9, thereby triggering a cascade of caspase activation ${ }^{11,12}$.

The inhibition of cytochrome $\mathrm{C}$ release and the prevention of binding to APAF-1 are carried out by Bcl-2 and Bcl-XL molecules, both anti-apoptotic Bcl-2 proteins located in the external mitochondrial membrane. Other proteins, besides the cytochrome C, can mediate the apoptotic process, such as Smac/DIABLO, apoptosis inducing factor, endonuclease $\mathrm{G}$ and OMI/HTRA2 (high-temperature-requirement protein A2) ${ }^{11}$.

The X-linked inhibitor of apoptosis (XIAP) is a protein whose activity mediates apoptosis resistance, its effects being mediated by the ability to directly suppress the caspases. It has recently been pursued as a new therapeutic target in solid tumors and is associated with poor survival among GBM patients ${ }^{13,14,15}$.

In order to know more about the mechanism of apoptosis in GBM, this study was developed to evaluate the gene expression of anti-apoptotic (XIAP and Bcl-2) and apoptotic (cytochrome C, caspase 9, APAF-1), caspase 3 and the Smac/DIABLO genes of the intrinsic pathway of apoptosis. This could contribute to a better understanding of the expression of these proteins in human glioblastoma, and possibly provide additional prognostic information for the development of new target therapies associated with the glioma apoptosis pathway, resulting in an improvement in treatment responses and patients outcomes.

\section{METHODS}

\section{Patient samples}

For analysis of this study, we used 30 consecutive samples diagnosed with glioblastoma, collected from 2006 to 2007 from adult patients (men and women), with a mean age of 45 years (average age with a histopathologic diagnosis based on WHO criteria) $)^{1,2}$, who were treated by the neurosurgery team of the Ribeirão Preto medical school clinical hospital, University of São Paulo. In addition, 10 white matter samples from patients with no tumor, with a drug-resistant epilepsy diagnosis who underwent surgery, were used as controls. All frozen tumor and control specimens were submitted to a microdissection process.

This study was approved by the Research Ethics Committee of Ribeirão Preto Medical School at the University of São Paulo. The committee is in agreement with the Helsinki Declaration requirements for research carried out on humans. Informed consent was also received from each patient (or their legal representative) involved in this project.

\section{RNA extraction and cDNA synthesis}

Total RNA was extracted with Trizol reagent (Applied Biosystems, USA) according to the manufacturer's instructions. For verification of the integrity of the RNA obtained, each sample was subjected to electrophoresis on agarose gel 1\% RNA and through the spectrophotometer (Nanodrop 2000 ) that provided the RNA concentration in a sample of $1 \mu \mathrm{l}$ to $2 \mu \mathrm{l}$. In addition to the concentration, this device provided us with values of a reference for the integrity of the samples (260/280 ratio). The ideal range to be obtained was 1.7 to 1.9 .

In preparation of real-time polymerase chain reaction (PCR), reverse transcription (RT-PCR) of RNA samples was performed using the High-Capacity cDNA kit (Applied Biosystems, USA).

\section{Analysis of gene expression patterns by RQ-PCR}

For the quantitative analysis of the genes being studied, caspase 9 (Assay ID Hs00154260_m1), cytochrome C (Assay ID Hs01588973_m1), APAF-1 (Assay ID Hs00559441_ m1), caspase 3 (Assay ID Hs00234385_m1), Smac/DIABLO (Assay ID 00219876_m1), XIAP (Assay AI 00236913_m1) and Bcl-2 (Assay ID 00608023_m1), the commercially-available system TaqMan Assay-on-demand was used (Applied Biosystems, Foster City, CA, USA). Reverse transcription was performed using $1 \mu \mathrm{g}$ total RNA for each sample in $20 \mu \mathrm{l}$ of the total reaction mixture. The cDNA obtained was diluted 1:10 and $4.5 \mu \mathrm{l}$ was used for each $10 \mu \mathrm{l}$ of the real-time quantitative RT-PCR (RQ-PCR) mixture using the TaqMan Master Mix (Applied Biosystems).

All reactions were carried out in duplicate and analyzed with the 7500 Sequence Detection System apparatus (Applied Biosystems). Data were analyzed using the ABI7500 Sequence Detection System software. The maximum 
standard deviation between duplicates was $10 \%$. The total RNA absorbed was normalized on the basis of the $\mathrm{Ct}$ value for $\beta$-actin gene (Hs0099999_m1). The variation of expression among samples was calculated by the $2-\Delta \Delta \mathrm{Ct}$ (cycle) method, with the mean delta $\mathrm{Ct}$ value of the control group being used as a calibrator. To obtain the Ct values, a threshold of 0.1 was established and the PCR conditions were: preheating at $50^{\circ}$ for $2 \mathrm{~min}$, denaturation at $95^{\circ}$ for $10 \mathrm{~min}$ and 50 cycles of amplification and quantification $\left(15 \mathrm{sec}\right.$. at $95^{\circ}$ and $1 \mathrm{~min}$. at $\left.60^{\circ}\right)$.

\section{Statistical analysis}

Comparisons of gene expression of the tumor and control samples were performed by nonparametric Mann-Whitney tests. The level of significance was set at $p<0.05$ in all analyses. The tests were accomplished with the support of the GraphPad Prism-version 4.0 program (GraphPad Software Inc, San Diego, CA, USA).

\section{RESULTS}

\section{Comparison of apoptotic and anti-apoptotic genes} mRNA levels in high grade gliomas and normal tissue

The expression of apoptotic (cytochrome C, APAF-1, caspase 9 , caspase 3, Smac/DIABLO) and anti-apoptotic genes (XIAP and Bcl-2) were analyzed using relative quantification of mRNA levels in normal brain and glioblastomas. Among the apoptotic genes (cytochrome $\mathrm{C}, \mathrm{p}=0.7906$; APAF-1, $\mathrm{p}=0.0831$; caspase 9, $\mathrm{p}=0.6506$; caspase $3, \mathrm{p}=0.1743$ and Smac/DIABLO, $\mathrm{p}=0.4630$ ), no significant differences in gene expression between high-grade glioma tumor and normal tissue were observed (Figure 1).

However, the anti-apoptotic genes (XIAP and Bcl-2) were expressed at higher levels in GBMs when compared to control samples ( $p<0.05$; Figure 2$)$.

\section{DISCUSSION}

Recent studies analyzing gene expression have shown that the treatment of glioblastoma cells with retinamide (apoptosis inducer) resulted in decreased levels of Bcl-2 and Bcl-X in glioblastoma cells. When associated with carmustine (a chemotherapy agent), it leads to a downregulation of Bcl-2 and $\mathrm{Bcl}$-X proteins in these cells and increases the apoptosis incidence in the U87 glioblastoma cellular lineage. In this way, it was demonstrated that the modulation of Bcl-2 and Bcl-X anti-apoptotic proteins levels may raise the sensitivity of the glioblastomas to chemotherapy ${ }^{16}$. In another study, Tirapelli et al. ${ }^{17}$, through immunohistochemical analysis of GBM samples, found high expression of Bcl-2, providing molecular evidence that the protein Bcl-2 can reduce cell death in GBM. The upregulation of the anti-apoptotic Bcl-2 and Bcl-XL and
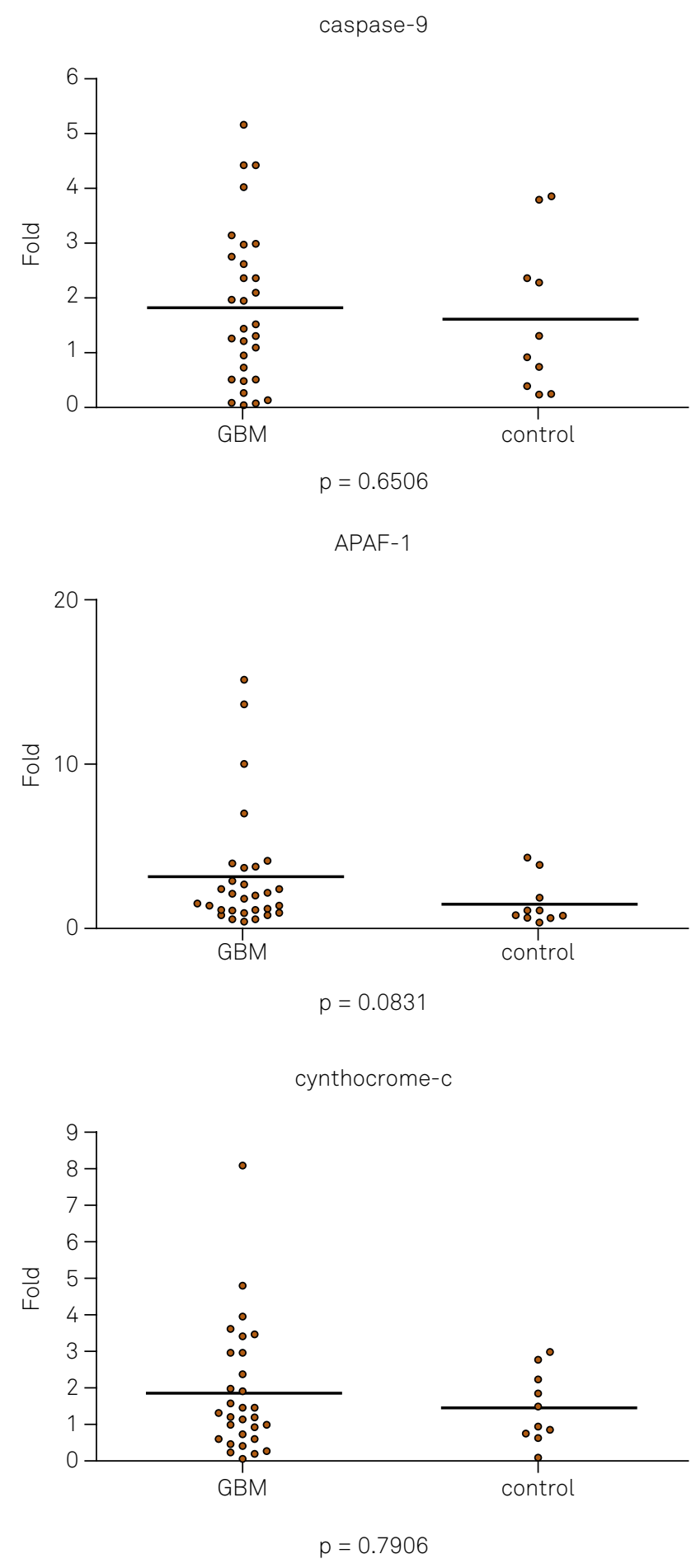

Figure 1. Profile expression of anti-apoptotic genes of apoptosome related to intrinsic pathway: cytochrome C, caspase 9 and APAF1 in the glioblastoma (GBM) and control samples. The solid line corresponds to the median value for each group.

downregulation of the pro-apoptotic Bax have been detected in recurrent GBMs, showing, in part, the resistance of GBM to TRAIL-directed treatments ${ }^{18}$. Our results support this hypothesis, demonstrating a significant difference in the expression of XIAP and Bcl-2, both anti-apoptotic genes, in glioblastomas, and it can suggest that the cellular death triggered by the 

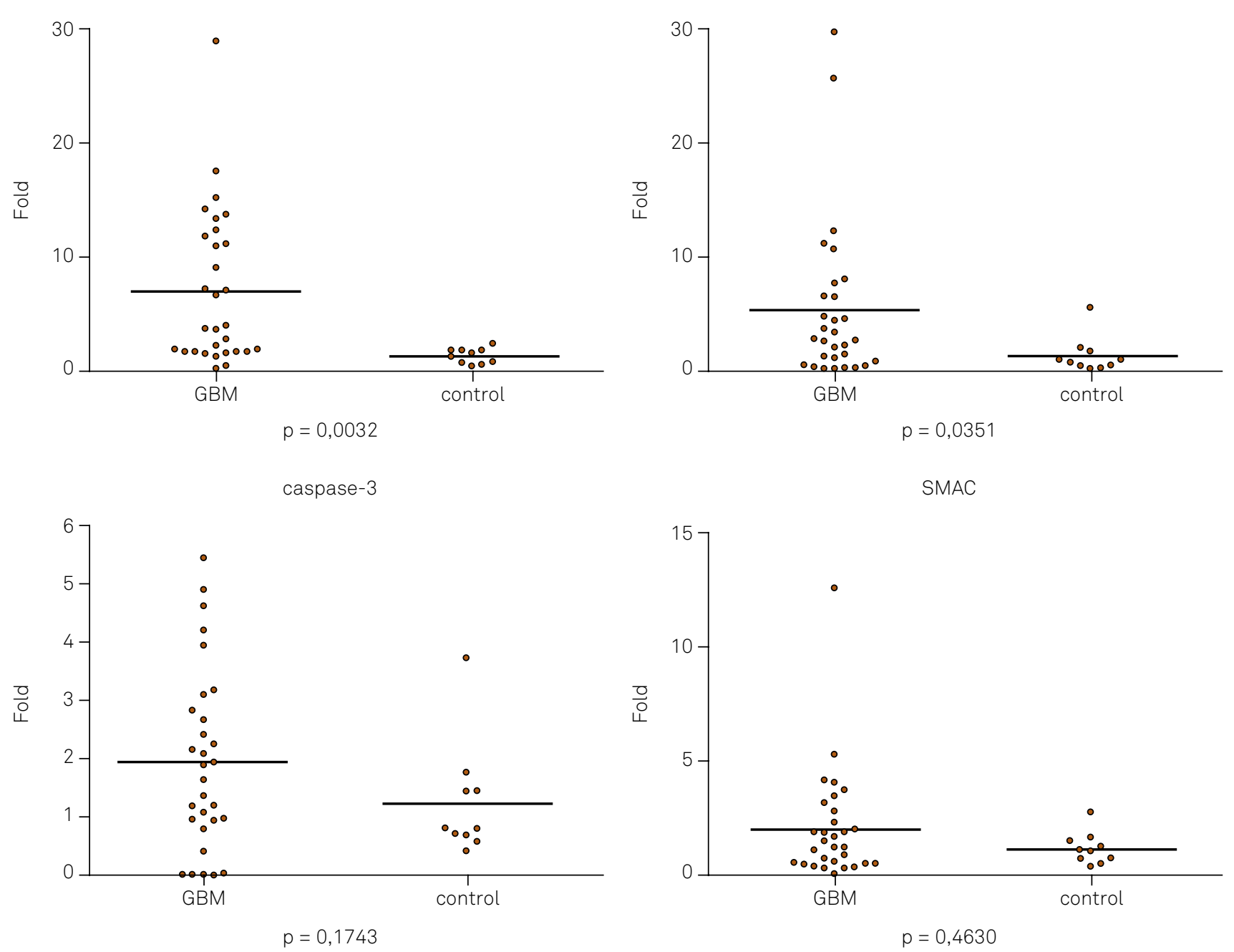

Figure 2. Profile expression of anti-apoptotic genes related to intrinsic pathway: XIAP and BcL-2 and apoptotic genes: caspase 3 and the Smac/DIABLO. The solid line corresponds to the median value for each group.

apoptosis intrinsic pathway was inhibited in these tumors. Strik et al., also showed that the changes in Bcl-2 family protein expression can result from radiochemotherapy, but also reflect the natural course of disease ${ }^{19}$.

Several proteins are released from the mitochondrial intermembrane space into the cytoplasm, including cytochrome $\mathrm{C}$ and Smac/DIABLO. Cytochrome $\mathrm{C}$ binds and activates the APAF-1 in the cytoplasm. The binding of cytochrome $\mathrm{C}$ to APAF-1 induces conformational changes that allow APAF-1 to bind ATP/dATP and form the apoptosome that activates caspase 9. In this way, it triggers a caspase activation cascade ${ }^{11}$. The glioblastoma samples showed low expression levels of mRNA of cytochrome C, APAF-1 and caspase 9 in our analysis, which suggests decreased apoptotic activity in these cells. These data are in accordance with a study carried out by Watanabe et al., who observed, through immunohistochemistry and RT-PCR, the low expression of loss of heterozygosity of 12q22-23 chromosome in $70 \%$ of 33 glioblastomas and the consequent inactivation of APAF-1 in the glioblastomas ${ }^{20}$.
The resistance to apoptosis in cells of human astrocytoma was also examined by Ceruti et al. using the induction of mitochondria-damaging agents. They reported that the resistance to the apoptosis was due to an intrinsic defect of caspase 9, leading to inhibition of enzyme activation and/or deteriorated interaction with proteins released by depolarization of the mitochondria ${ }^{21}$. The caspase 3 has been identified as an apoptosis key mediator. Once activated, it is responsible for proteolytic cleavage of a broad spectrum of cellular targets, leading to cell death ${ }^{22}$. The degradation of the PARP (polyADP-ribose polymerase), actin and SREBP (sterol regulatory element binding protein) related to the apoptosis $^{23}$, confirms the activation of caspase 3 and suggests an irreversible phase in the death process by apoptosis in tumors. Ray et al. ${ }^{24}$ showed that the increase of the expression of the pro-apoptotic genes, Bax, CALPAIN (cysteine protease dependent) and caspase 3 associated with DNA fragmentation, indicates that the apoptosis is a mechanism that causes the death of malignant tumor cells and increasing the apoptosis in the therapeutic process may result in a reduction of 
tumor size ${ }^{24}$. In this study, there was no significant difference in the expression of caspase 3 between glioblastoma and normal brain tissue samples, providing evidence of an unlikely occurrence of apoptosis in these tumors.

The Smac/DIABLO that binds to XIAP, and possibly to other IAPs, is released by the mitochondria, in a manner that keeps caspases away from XIAP. Therefore, the Smac/ DIABLO is an IAP negative regulator and, consequently, a molecule that increases apoptosis ${ }^{12}$. In the present study, there were no significant changes in Smac/DIABLO expression, suggesting the connection of the XIAP and caspase 9, and, in this way, the inhibition of apoptosis. These data are compatible with the results of Rajalingan et al. ${ }^{25}$, who, in a study with HeLa cells, could not detect any compensation for Smac loss as the formation of P17 active fragment of caspase 3 and induction of apoptosis were clearly Smac dependent ${ }^{25}$. Smac deficient cells are protected from apoptosis or another form of programmed cellular death. The XIAP is a potent inhibitor of cell death that has been attributed largely to its ability to suppress specific caspases ${ }^{12}$. The interaction with the caspase 9 and 3 allows the XIAP to block the caspases activities efficiently, preventing, in this way, the proteolytic cascade. If the apoptotic stimulus persists, the progressive generation of activated caspases, together with a competition among the mitochondrial proteins that block the XIAP activity, may overwhelm the protective effect of the XIAP ${ }^{26}$.

In conclusion, despite the limitations of our study due to the small number of samples, the results demonstrated that there are differences in the expressions of Bcl-2 and XIAP genes in glioblastomas and this can contribute for the inhibition of programmed cell death, thus explaining one of the mechanisms of resistance of this type of tumor. Moreover, our results may provide additional information to enable the development of new therapeutic strategies capable of specifically targeting the apoptotic pathway in gliomas, aiming for better treatment responses and patient outcomes.

\section{References}

1. Louis DN, Ohgaki H, Wiestler OD, Cavenee WK, Burger PC, Jouvet A et al. The 2007 WHO classification of tumours of the central nervous system. Acta Neuropathol. 2007;114(2):97-109. https://doi.org/10.1007/s00401-007-0243-4

2. Louis DN, Perry A, Reifenberger G, Deimling A, Figarella-Branger D, Cavenee WK et al. The 2016 World Health organization classification of tumors of the central nervous system: a summary. Acta Neuropathol. 2016;131(6):803-20. https://doi.org/10.1007/s00401-016-1545-1

3. Ceccarelli M, Barthel FP, Malta TM, Sabedot TS, Salama SR, Murray BA et al. Molecular profiling reveals biologically discrete subsets and pathways of progression in diffuse glioma. Cell. 2016;164(3):550-63. https://doi.org/10.1016/j.cell.2015.12.028

4. Frei K, Ambar B, Adachi N, Yonekawa Y, Fontana A. Ex vivo malignant glioma cells are sensitive to Fas (CD95/APO-1) ligand-mediated apoptosis. J Neuroimmunol. 1998;87(1-2):105-13. https://doi.org/10.1016/S0165-5728(98)00065-4

5. Stupp R, Hegi ME, Gilbert MR, Chakravarti A. Chemoradiotherapy in malignant glioma: standard of care and future directions. J Clin Oncol. 2007;25(26):4127-36. https://doi.org/10.1200/JC0.2007.11.8554

6. Ohgaki H, Kleihues P. Genetic pathways to primary and secondary glioblastoma. Am J Pathol. 2007;170(5):1445-53. https://doi.org/10.2353/ajpath.2007.070011

7. Griguer CE, Oliva CR. Bioenergetics pathways and therapeutic resistance in gliomas: emerging role of mitochondria. Curr Pharm Des. 2011;17(23):2421-7. https://doi.org/10.2174/138161211797249251

8. Network CG. Comprehensive genomic characterization defines human glioblastoma genes and core pathways. Nature. 2008;455(7216):1061-8. https://doi.org/10.1038/nature07385

9. Verhaak RG, Hoadley KA, Purdom E, Wang V, Qi Y, Wilkerson MD et al. Integrated genomic analysis identifies clinically relevant subtypes of glioblastoma characterized by abnormalities in PDGFRA, IDH1, EGFR, and NF1. Cancer Cell. 2010;17(1):98-110. https://doi.org/10.1016/j.ccr.2009.12.020

10. Goldar S, Khaniani MS, Derakhshan SM, Baradaran B. Molecular mechanisms of apoptosis and roles in cancer development and treatment. Asian Pac J Cancer Prev. 2015;16(6):2129-44. https://doi.org/10.7314/APJCP.2015.16.6.2129
11. Riedl SJ, Shi Y. Molecular mechanisms of caspase regulation during apoptosis. Nat Rev Mol Cell Biol. 2004;5(11):897-907. https://doi.org/10.1038/nrm1496

12. Salvesen GS, Duckett CS. IAP proteins: blocking the road to death's door. Nat Rev Mol Cell Biol. 2002;3(6):401-10. https://doi.org/10.1038/nrm830

13. Emery IF, Gopalan A, Wood S, Chow KH, Battelli C, George $J$ et al. Expression and function of ABCG2 and XIAP in glioblastomas.J Neurooncol. 2017;133(1):47-57. https://doi.org/10.1007/s11060-017-2422-z

14. Vellanki SH, Grabrucker A, Liebau S, Proepper C, Eramo A, Braun V et al. Small-molecule XIAP inhibitors enhance gamma-irradiation-induced apoptosis in glioblastoma. Neoplasia. 2009;11(8):743-52.

15. Lee FA, Zee BC, Cheung FY, Kwong P, Chiang CL, Leung KC et al. Randomized Phase II study of the X-linked Inhibitor of Apoptosis (XIAP) antisense AEG35156 in combination with sorafenib in patients with advanced hepatocellular carcinoma (HCC). Am J Clin Oncol. 2016;39(6):609-13. https://doi.org/10.1097/C0C.0000000000000099

16. Lytle RA, Jiang Z, Zheng X, Higashikubo R, Rich KM. Retinamide-induced apoptosis in glioblastomas is associated with down-regulation of $\mathrm{Bcl}-\mathrm{xL}$ and $\mathrm{Bcl}-2$ proteins. J Neurooncol. 2005;74(3):225-32. https://doi.org/10.1007/s11060-005-7305-z

17. Tirapelli LF, Bolini PH, Tirapelli DP, Peria FM, Becker AN, Saggioro FP et al. Caspase-3 and Bcl-2 expression in glioblastoma: an immunohistochemical study. Arq Neuropsiquiatr. 2010;68(4):603-7. https://doi.org/10.1590/S0004-282X2010000400023

18. Krakstad C, Chekenya M. Survival signalling and apoptosis resistance in glioblastomas: opportunities for targeted therapeutics. Mol Cancer. 2010;9:135. https://doi.org/10.1186/1476-4598-9-135

19. Strik H, Deininger M, Streffer J, Grote E, Wickboldt J, Dichgans $J$ et al. BCL-2 family protein expression in initial and recurrent glioblastomas: modulation by radiochemotherapy. J Neurol Neurosurg Psychiatry. 1999;67(6):763-8. https://doi.org/10.1136/jnnp.67.6.763

20. Watanabe T, Hirota Y, Arakawa Y, Fujisawa H, Tachibana O, Hasegawa M et al. Frequent LOH at chromosome 12q22-23 and Apaf-1 inactivation in glioblastoma. Brain Pathol. 2003;13(4):431-9. https://doi.org/10.1111/j.1750-3639.2003.tb00474.x 
21. Ceruti S, Mazzola A, Abbracchio MP. Resistance of human astrocytoma cells to apoptosis induced by mitochondria-damaging agents: possible implications for anticancer therapy. J Pharmacol Exp Ther. 2005;314(2):825-37. https://doi.org/10.1124/jpet.105.085340

22. Shi Y. Mechanical aspects of apoptosome assembly. Curr Opin Cell Biol. 2006;18(6):677-84. https://doi.org/10.1016/j.ceb.2006.09.006

23. Konstantinidou AE, Givalos N, Gakiopoulou H, Korkolopoulou P, Kotsiakis X, Boviatsis E et al. Caspase-3 immunohistochemical expression is a marker of apoptosis, increased grade and early recurrence in intracranial meningiomas. Apoptosis. 2007;12(4):695-705. https://doi.org/10.1007/s10495-006-0001-4
24. Ray SK, Patel SJ, Welsh CT, Wilford GG, Hogan EL, Banik NL. Molecular evidence of apoptotic death in malignant brain tumors including glioblastoma multiforme: upregulation of calpain and caspase-3.J Neurosci Res. 2002;69(2):197-206. https://doi.org/10.1002/jnr.10265

25. Rajalingam K, Oswald M, Gottschalk K, Rudel T. Smac/DIABLO is required for effector caspase activation during apoptosis in human cells. Apoptosis. 2007;12(8):1503-10. https://doi.org/10.1007/s10495-007-0067-7

26. Loo G, Saelens X, Gurp M, MacFarlane M, Martin SJ, Vandenabeele P. The role of mitochondrial factors in apoptosis: a Russian roulette with more than one bullet. Cell Death Differ. 2002;9(10):1031-42. https://doi.org/10.1038/sj.cdd.4401088 